\title{
Energy/Macronutrient Density and Sensory Evaluation of Formulated Complementary Foods for use in Low-Income Populations in Northern Nigeria
}

\author{
Kelechi-Ebisike Vivian $\mathbf{0}^{1 *}$, Solomon Mariam $\mathrm{D}^{1}$, Jaryum Kiri $\mathbf{H}^{1}$, \\ Ebisike Kelechi J ${ }^{2}$, Mshelia $\mathbf{P}^{\mathbf{1}}$ and Danjin Mela $^{\mathbf{3}}$ \\ ${ }^{1}$ Department of Biochemistry, University of Jos, Nigeria \\ ${ }^{2}$ Department of Paediatrics, Federal Teaching Hospital, Gombe, Nigeria \\ ${ }^{3}$ College of Nursing and Midwifery, Gombe, Nigeria \\ *Corresponding Author: Kelechi-Ebisike Vivian O, Department of Biochemistry, \\ University of Jos, Nigeria.
}

DOI: 10.31080/ASNH.2020.04.0656

\begin{abstract}
Complementary feeding in Low-and- Middle-Income-Countries (LMICs) such as Nigeria remains a major concern as the burden of childhood malnutrition has worsened in Northern Nigeria.

The study was designed to formulate complementary foods using available staples, compare energy and macronutrient density to international standards, estimate the cost of production of the blends and carry out a sensory evaluation on the diets. Ingredients were purchased from a grain market in Gombe, Gombe state, Nigeria. The diets were formulated by a 60:40 (cereal/tuber : legume) mix ratio using a household level approach.

Diet A: Sweet potatoes + millet + groundnut + bambaranut $(25: 35: 30: 10 \% \mathrm{w} / \mathrm{w})$

Diet B: Tiger nut + millet + groundnut + bambaranut (25:35:30:10\% w/w). Cereals, tubers and legumes were prepared using simple household level approaches. Diets were constituted and homogenously blended into fine powder, sieved, packed and labeled. Proximate composition analysis to determine macronutrient and energy density was carried out using standard analytical methods. Analysis of data was done using descriptive statistics.Th e results show that energy density of diets were between $4.04 \pm 1.84 \mathrm{kcal} / \mathrm{g}$ $-4.13 \pm 2.84 \mathrm{kcal} / \mathrm{g}$, crude protein $(15.84 \pm 0.59 \%-18.28 \pm 0.35 \%)$, crude fat $(5.84 \pm 0.4 \%-8.41 \pm 0.21)$ and were comparable to International Food Standard values as amended in 2017. Moisture values were between $1.17 \pm 0.12 \%-2.46 \pm 0.15 \%$ suggesting longer shelf life for the foods. Cost of production of $400 \mathrm{~g}$ commercial packaging was less than 1USD (N272). The diets had good energy and macronutrient density, a very low cost of production and overall acceptability which presents as a strong tool in tackling malnutrition in low income populations.

Keywords: Complementary Feeding; Energy Density; Macronutrient Density; Northern Nigeria
\end{abstract}

\section{Introduction}

The second six months in a child's life opens with the complementary feeding period. During this period, breast feeding, though no longer adequate to meet the growing child's nutritional needs, is expected to continue. It is thus anticipated that complementary foods provide energy, macronutrients and micronutrients to bridge the gaps between daily requirements for infants and young children and the amount consumed through breastfeeding [1]. Unfortunately, complementary foods which ought to be energy and nutrient dense are more commonly of low quality in Nigeria [2]. Consequently, children aged 6 - 24 months are the most vulnerable group for malnutrition as $41 \%$ deaths of children in developing countries in this age group (2.3 million) is linked to this menace [3]. Nigeria has been ranked the country with the second highest burden of stunted children in the world with a prevalence of $32 \%$ of the children under five years of age. The states in northern Nigeria where malnutrition and insecurity now go hand in hand, are the most affected with wasting and stunting [4], thus, it is not unusual to see mothers carrying their malnourished babies around as though everything is normal; a large number not even aware of the consequences of leaving such children unattended to. This is very worrisome and indeed an emergency situation.

Low energy intake leads to reduced physical activity which is important for the social development of the child. In the long run, it may lead to disease of Protein-Energy Malnutrition (PEM) as metabolism of protein sets in to provide energy for the child, hence, energy-dense foods are very important to meet up with the energy requirement of the child. This is however, largely dependent on the energy density of the diets served. Vegetable source proteins with low biological value (BV) can also be mixed (protein complementation) to overcome the limiting amino acid and equal a high biological value [5]. In Nigeria, especially in the Northern part of the country, cereals are reported to be the major source of energy and protein in the diets of the people and the major cereals cultivated are sorghum, millet, maize and rice [6]. Legumes are an affordable source of protein and fat and are gaining appreciable interest globally because of the demand for healthier foods. They represent an important component of human nutrition (particularly older infants and young children), especially in the develop- 
ing countries, where they are considered as a complement to the deficiency of protein from cereals, roots, and tubers which are the country's staples [7]. Nutritionally, roots and tubers provide one of the cheapest and available sources of dietary energy, in the form of carbohydrates [8].

Issues on complementary foods and complementary feeding have taken the centre stage in current Infant and Young Child Feeding (IYCF) research. Ultimately, improving infant and young child health will require a mix of community-based interventions involving nutrition education for caregivers, enhancing maternal nutrition, sustainable support for exclusive breastfeeding, complementary feeding best practices and effective implementation of agricultural and nutrition policies. With the twin problem of the rising figures of malnutrition across the globe and the current economic situation especially in developing nations like ours, it becomes necessary to view optimal complementary feeding through the lens of taking actions that are sustainable. Therefore, strong consideration ought to be given to the utilization of indigenous staples in complementary food formulation due to their availability, affordability and acceptability [9]. The aim of the study is thus, to formulate low-cost cereal-legume based foods modified with tubers (sweet potatoes and tiger nut), assess the energy density and macronutrient content of the food and compare values with reference standard [10].

\section{Materials and Methods}

Formulation of Diets: Food stuffs were selected based on availability and nutritional content as documented in the West African food composition table [11]. The foodstuffs for the formulation of the diets were purchased from Tudun Hatsi market, a central grain market in Gombe Metropolis. Two diets (Diet A and Diet B) were formulated. Diet A had pearl millet (Pennisetum glaucum), sweet potatoes (Ipomoea batatas), groundnut (Arachis hypogaea) and bambara nut (Vigna subterranean).Diet B had no sweet potato but contained tiger nut (Cyperus esculentus). Preparation of Diets: The diets were formulated using a 60:40(cereal: legume) mix ratio $[3,12]$. Millet grains were thoroughly washed and drained repeatedly then spread on a large clean surface until when completely dried. Groundnut and bambara nut were cleaned and wounded seeds removed. They were then, separately roasted as in rural communities [13]. The legumes were put in roasting pans and placed under direct heat from fire wood. The legumes were continuously stirred for about 20 minutes. Afterwards, the roasted seeds were allowed to cool and the burnt ones sorted out. Groundnut peels were removed partially removed by traditional methods of rolling glass bottles over the groundnut on a clean sack and the chaff was blown away. Dried pale yellow sweet potatoes and dried tiger nut were manually sorted and cleaned. Ingredients for each diet were weighed using electronic kitchen scale (Model No.SF-400).

- $\quad$ Diet A - Millet: Sweet Potatoes: Groundnut: Bambara Nut $(35: 25: 30: 10 \% \mathrm{w} / \mathrm{w})$

- $\quad$ Diet B- Millet: Tiger Nut: Groundnut: Bambara Nut (Experimental) $(35: 25: 30: 10 \% \mathrm{w} / \mathrm{w})$.
The ingredients were appropriately weighed, mixed and then milled into smooth homogenous powders using household level approaches [9]. The blends were sieved through a locally made fine mesh $(0.5 \mathrm{~mm})$, stored in bags and properly labelled, then taken for nutritional analysis.

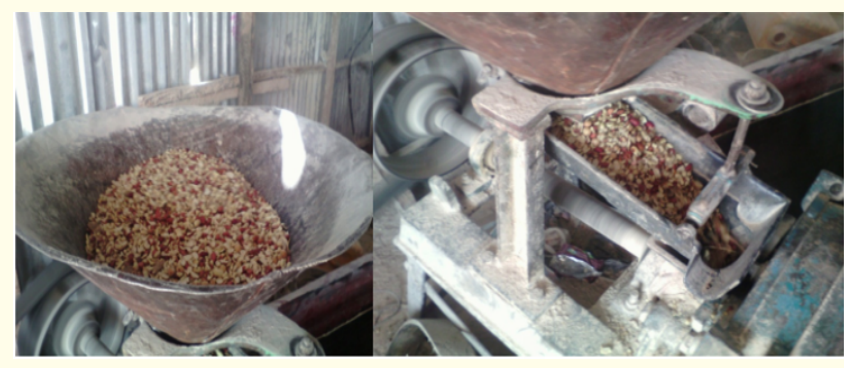

Plate 1: Household level approach for formulation of complementary foods.

Analysis of Diet: Proximate composition analysis was carried out using standard methods [14] to determine the moisture content of the formulated diets which was then calculated in percentage as

Moisture content $\%=\frac{\text { Moisture loss }}{\text { Sample weight }} \times \frac{100}{1}$

Crude Fat determination was done by the Soxhlet extraction method and was also calculated in percentage as

Crude fat $\%=\frac{\text { Weight of fat }}{\text { Sample weight }} \times \frac{100}{1}$

Protein content determination was done by the estimation of total nitrogen by Kjeldahl method [14].

Protein values of the samples were calculated by multiplying the total nitrogen value by a factor of 6.25 .

Protein $(\%)=\frac{(\mathrm{A}-\mathrm{B}) \times \mathrm{N} \times 14.007 \times 6.25}{W}$

Where:

$\mathrm{A}=$ Volume $(\mathrm{ml})$ of $0.2 \mathrm{~N} \mathrm{HCl}$ used in sample titration

$\mathrm{B}=$ Volume $(\mathrm{ml})$ of $0.2 \mathrm{~N} \mathrm{HCl}$ of blank titration

$\mathrm{N}=$ Normality of $\mathrm{HCl}$

$\mathrm{W}=$ Weight $(\mathrm{g})$ of sample

$14.007=$ Atomic weight of nitrogen

6.25 = Protein- nitrogen conversion factor for fish and its by-products.

Crude fibre was determined after extraction of moisture and fat and calculated

Crude fibre $\%=\frac{\text { Weight of fibre }}{\text { Weight of Sample }} \times \frac{100}{1}$

The total carbohydrate content (Nitrogen free extract) of the diet samples was obtained by difference by subtracting the sum of percentage crude protein, crude fat and ash from 100 [15]. 
Nitrogen free extract (NFE) $=100-($ sum of $\%$ crude protein $+\%$ crude fat $+\%$ ash)

Energy Value Determination (Kilojoules (KJ)/Kilocalories (kcal))

The metabolizable energy value of the food samples was calculated by applying the energy conversion factors (modified Atwater factors). The energy values are $17 \mathrm{~kJ} / \mathrm{g}$ ( $4.0 \mathrm{kcal} / \mathrm{g}$ ) for protein, 37 $\mathrm{kJ} / \mathrm{g}(9.0 \mathrm{kcal} / \mathrm{g})$ for fat and $17 \mathrm{~kJ} / \mathrm{g}(4.0 \mathrm{kcal} / \mathrm{g})$ for carbohydrates [11].

Total Energy Value $(\mathrm{kcal})=$ Sum of $($ gram of each nutrient in $\operatorname{diet}(\mathrm{g} / 100 \mathrm{~g}) \mathrm{x}$ conversion factor).

Cost of production of formulated diets: The cost of producing 400 grams of the diet was estimated after taking into account the cost of ingredients, preparation and loses from processing.

Sensory evaluation was also done by a seventeen-member panel which included mothers of children aged 6 - 23 months in a well illuminated and ventilated room. The participants were briefed on what was expected of them to do. After they had shown good understanding of the procedure, the ready-to-eat diets A and B were set up to evaluate taste, aroma, colour, texture (mouth feel) and overall acceptability of the foods. The scoring method was a (ninepoint) hedonic scale which ranged from 1(dislike extremely) to 9 (like extremely). A glass of water was provided for each panellist to rinse their palette after each tasting to avoid bias. After the exercise, the scoring sheets were collected from the panellists who were also appreciated. The data was taken for statistical analysis.

Statistical Analysis: Results were expressed as mean \pm standard deviation and statistical difference was seen at $\mathrm{p}<0.05$.

\section{Results}

Table 1 shows the proximate composition of the results of the formulated complementary foods, Diets A and B. It was observed that the Diet $B$ had higher protein content $(16.72 \pm 0.67)$ and higher crude fat content $(8.41 \pm 0.21)$ which reflected in its higher energy value $(417.81 \pm 1.69)$. Diet $\mathrm{B}$ also had a lower moisture content $(1.14 \pm 0.12)$. Diet A had a significantly higher carbohydrate (NFE) content. Table 2 shows the comparison of the diets with the reference values [10] for the formulation of complementary foods. Diets A and B met the reference standards except for the fat content energy value. Table 3 shows the estimated cost of production of the complementary foods. The cost of production of 400 grams of the diets was less than 1 US Dollar (N272.50). Figure 1 also shows the sensory analysis of the diets. Diet B had higher value for taste, colour, mouth feel and overall acceptance.

\section{Discussion}

The use of locally available foodstuffs native to communities is being strongly advocated especially in Low-and-Middle-IncomeCountries (LMICs) where insufficient access to food is a leading

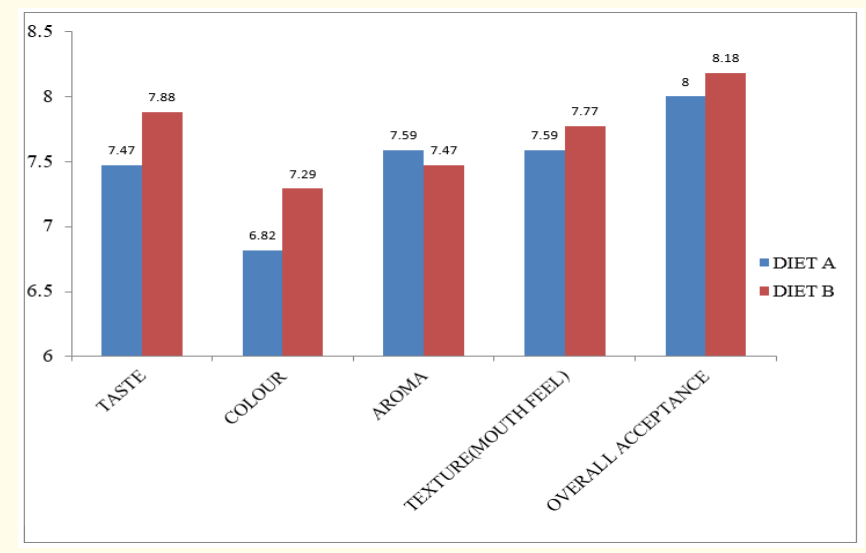

Figure 1: Sensory Evaluation of Complementary Foods Using Hedonic Scale. Hedonic scale: 1: Dislike Extremely; 2: Dislike Very Much; 3: Dislike Moderately; 4: Dislike Slightly; 5: Neither Like/Dislike; 6: Like Slightly; 7: Like Moderately; 8: Like Very Much; 9: Like Extremely.

\begin{tabular}{|l|c|c|}
\hline \multicolumn{1}{|c|}{ Nutrient $\mathbf{( g / 1 0 0 g )}$} & Diet A & Diet B \\
\hline Crude Protein & $15.84 \pm 0.59^{\mathrm{a}}$ & $16.72 \pm 0.67^{\mathrm{b}}$ \\
\hline Crude Fat & $7.05 \pm 0.08^{\mathrm{a}}$ & $8.41 \pm 0.21^{\mathrm{b}}$ \\
\hline Crude Fibre & $2.95 \pm 0.2^{\mathrm{a}}$ & $3.47 \pm 0.15^{\mathrm{b}}$ \\
\hline Moisture & $2.45 \pm 0.15^{\mathrm{a}}$ & $1.14 \pm 0.12^{\mathrm{b}}$ \\
\hline Ash & $2.58 \pm 0.59^{\mathrm{a}}$ & $2.43 \pm 0.31^{\mathrm{b}}$ \\
\hline Nitrogen Free Extract (NFE) & $71.67 \pm 0.28^{\mathrm{a}}$ & $68.80 \pm 0.48^{\mathrm{b}}$ \\
\hline Energy Value (Kcal/100g) & $413.46 \pm 1.84^{\mathrm{a}}$ & $417.81 \pm 1.69^{\mathrm{b}}$ \\
\hline
\end{tabular}

Table 1: Proximate Nutrient Composition of Formulated Diets.

Values with statistical analysis are means \pm SD of three determinations.

Figures in the same horizontal row with different superscript are statistically different at $\mathrm{P}<0.05$

\begin{tabular}{|l|c|c|c|}
\hline $\begin{array}{l}\text { Proximate } \\
\text { properties }\end{array}$ & Diet & $\begin{array}{c}\text { Energy values } \\
\text { from Diets }\end{array}$ & $\begin{array}{c}\text { Codex Reference } \\
\text { values* }\end{array}$ \\
\hline Crude Protein & $\mathrm{A}$ & $15.32 \%$ & $6-15 \%$ \\
\hline & $\mathrm{B}$ & $16.01 \%$ & $6-15 \%$ \\
\hline Crude Fat & $\mathrm{A}$ & $15.43 \%$ & up to $20 \%$ \\
\hline & $\mathrm{B}$ & $18.12 \%$ & up to $20 \%$ \\
\hline Crude Fibre & $\mathrm{A}$ & $2.95 \mathrm{~g} / 100 \mathrm{~g}$ & $<5 \mathrm{~g} / 100 \mathrm{~g}$ \\
\hline & $\mathrm{B}$ & $3.47 \mathrm{~g} / 100 \mathrm{~g}$ & $<5 \mathrm{~g} / 100 \mathrm{~g}$ \\
\hline Energy Density & $\mathrm{A}$ & $4.13 \mathrm{kcal} / \mathrm{g}$ & at least $4.00 \mathrm{kcal} / \mathrm{g}$ \\
\hline & $\mathrm{B}$ & $4.17 \mathrm{kcal} / \mathrm{g}$ & at least $4.00 \mathrm{kcal} / \mathrm{g}$ \\
\hline
\end{tabular}

Table 2: Macronutrient and Energy Density of Formulated Diets as Compared to Reference Values.

Codex Alimentarius guidelines as amended in 2017

Proximate property $\mathrm{x}$

$\%$ Energy value from diet $=\frac{\text { corresponding At water factor }}{\text { Energy density of the diet }} \times 100$ 
Energy/Macronutrient Density and Sensory Evaluation of Formulated Complementary Foods for use in Low-Income Populations in Northern Nigeria

119

\begin{tabular}{|l|c|c|c|}
\hline \multicolumn{1}{|c|}{ Food Stuff } & Quantity Needed in 1000g & Current Price (1000g) & Price of Fraction Needed \\
\hline Millet & $350 \mathrm{~g}$ & $\mathrm{~N} 200(\$ 0.55)$ & $\mathrm{N} 70(\$ 0.19)$ \\
\hline $\begin{array}{l}\text { Tiger Nut/Sweet } \\
\text { Potato }\end{array}$ & $250 \mathrm{~g}$ & $\mathrm{~N} 300(\$ 0.82)$ & $\mathrm{N} 75(0.21)$ \\
\hline Bambara Nut & $100 \mathrm{~g}$ & $\mathrm{~N} 500(\$ 1.37)$ & $\mathrm{N} 50(\$ 0.14)$ \\
\hline Groundnut & $300 \mathrm{~g}$ & $\mathrm{~N} 500(\$ 1.37)$ & $\mathrm{N} 150(\$ 0.41)$ \\
\hline Preliminary Preparations (Roasting, Cleaning) & & & $\mathrm{N} 100(\$ 0.27)$ \\
\hline Milling & & & $\mathrm{N} 100(\$ 0.27)$ \\
\hline & & Total cost of $1000 \mathrm{~g}$ of diet & $\mathrm{N} 545(\$ 1.49)$ \\
\hline & $\begin{array}{c}\text { Cost of popular brand }(400 \mathrm{~g}) \\
\mathrm{N} 1,500(\$ 4.12)\end{array}$ & & \\
\hline
\end{tabular}

Table 3: Estimated Cost of Formulated Diets.

Assuming a $20 \%$ loss to milling, sieving and other factors, $800 \mathrm{~g}$ would cost N545 (\$1.49), therefore, $400 \mathrm{~g}$ will cost $\mathrm{N} 545 / 2=\mathrm{N} 272.50)(\$ 1.49 / 2=\$ 0.75)$.

driver of childhood malnutrition at household/family levels [16]. While pursuing this stake, it is imperative that guidelines on the formulation of complementary foods to meet international food standards be adhered. The diets were formulated in accordance with Codex guidelines. The energy densities of the formulated foods were between $4.13 \mathrm{kcal}-4.17 \mathrm{kcal} / \mathrm{g}$ which is in line with the minimum $4.00 \mathrm{kcal} / \mathrm{g}$ standard requirement. Similar studies of where energy values of foods made from a 60:40 blend of maize, bambara nut and cowpea were between $4.19 \mathrm{kcal} / \mathrm{g}-4.29 \mathrm{kcal} / \mathrm{g}$ [12] and where complementary food formulations used in a randomised control trial of children aged 6 - 12 months had energy values of $4.12 \mathrm{kcal} / \mathrm{g}(1731 \mathrm{~kJ})$ [17] agrees with the findings of this study. Findings from a Malawian study showed children who consumed a higher density food, 3.5 times denser, had greater weight gain than their counter parts after a 6 months intervention period [18], hence low energy density in complementary foods may be implicated in energy shortfalls and poor weight gain during the complementary feeding period. This is consistent with earlier findings of a clinical trial where the effect of dietary energy was measured on malnourished children. It was observed that even though the amounts of food consumed for the high density diets was lower than the volume consumed for the low density diets, the energy derived from the former, was significantly greater [19]. Carbohydrates take over from fat during the complementary feeding as the primary source of energy [20], hence, its availability is of utmost importance in locally formulated blends. The carbohydrate contents of the formulated diets in the present study ranges from $68.80 / 100 \mathrm{~g}$ to $71.67 \mathrm{~g} / 100 \mathrm{~g}$. These values are higher than those obtained from sweet potatoes based infant foods fortified with cowpea and peanut $(42.8 \mathrm{~g} / 100 \mathrm{~g}-54.1 \mathrm{~g} / 100 \mathrm{~g})$ [21]. The lower carbohydrate content is probably due to the use of sweet potatoes as the chief source of carbohydrates (60 - 70\%) as roots/tubers provide only one-third of energy that an equal weight of grains will supply as a result of their high water content [8].The Codex guidelines for the formulation of complementary foods necessitates the inclusion of fats and/or oils for the purpose of increasing the energy density, appreciable presence of essential fatty acids and reducing the total volume of the food consumed. Even though the formulated diets did not meet up the reference value, the values were considerably higher in Diet B (18.12\%). Findings from other studies are comparable with this study as fat contributions of $11.8 \%-15.89 \%$ [22] and $13.9 \%-15.9 \%$ [12] were calculated. The high fat content of Diet $\mathrm{B}(18.12 \%)$ in our study is attributable to tiger nut tuber ( $25 \%$ of the blend) included in the mix which has a high fat content of about $26.3 \mathrm{~g} / 100 \mathrm{~g}$ [11]. Complementary foods made with 55\% - $75 \%$ tiger nut, $15 \%$ - $35 \%$ soya beans and $10 \%$ full cream milk had calculated energy derived from fat to be $27.82 \%-33 \%$ [23]. Total fat intake has been reported to be associated with the intake of lipid-soluble antioxidants such as vitamin $\mathrm{E}$ that are considered to reduce oxidation of circulating cholesterol and low-density lipoproteins and, thereby, long-term cardiovascular risk [24].

Protein content of formulated complementary foods are set at a minimum of $6 \%$ and should typically not exceed $15 \%$ when all other factors (which may include losses during cooking) are considered. The protein content of the diets in this study (contribution to energy value) were $15.32 \%$ (Diet A) and $16.01 \%$ (Diet B). This follows the trend of complementary foods formulated on a $60: 40$ ratio for cereals and legumes in one study which gave highest calculated values of $18.90 \%$ [12], however, another study utilizing the same ratio gave crude values of protein at $6.37 \mathrm{~g} / 100 \mathrm{~g}-7.88 \mathrm{~g} / 100 \mathrm{~g}$ [3]; the difference in findings may be in the combination of legumes and processing methods. The capacity of dietary protein to support maintenance and growth of body tissues is dependent on the quantity and proportion of essential amino acids contained in the protein [20] hence when vegetable source proteins regarded as incomplete proteins as in cereals and legumes are mixed, protein complementation improves the biological value of such foods.

Modest quantities of less than 5grams per 100 grams of fibre have been recommended in the formulation of complementary foods. In as much as dietary fibre helps to regulate bowel movement, softens faeces and increase faecal bulk hence preventing constipation, when in excess, it may decrease appetite in infants and young children [1]. Dietary fibre contents of the formulated diets 
fell within the limit $(2.95 \mathrm{~g} / 100 \mathrm{~g}-3.84 \mathrm{~g} / 100 \mathrm{~g})$. Lower dietary fibre values found in other studies $[3,12]$ may be traced back to the processing methods such as malting and steeping utilized in the studies. Researchers are of the opinion that complementary foods with less than $10 \%$ moisture content has potential of inhibiting microbial growth and extending shelf life of the products $[25,26]$. The moisture content of Diet B was 1.14\%, while Diet A was 2.45\% respectively. Higher moisture content of $6.29 \%-7.37 \%$ have been reported [25] probably due to the use of taro (cocoyam) in up to $50 \%$ of the blend since roots and tubers are known for their high water content.

An attempt to estimate the cost of 400grams of the formulated diets brought the market price to N272.50, which is less than one US Dollar (\$0.75). The formulated diets were more than six times cheaper than a popularly demanded proprietary formula which costs N1500.

Sensory qualities of diets A and B diets showed no significant difference at $(p>0.05)$ and good overall acceptability on the hedonic scale, however, Diet B was seen to have better scores on the overall.

\section{Conclusion}

The diets met the standards for the formulation of complementary foods using locally sourced ingredients. The sensory qualities together with the extremely low cost of production relative to the brands in the market raise the potential of the diets as sustainable tools for tackling malnutrition in low-income populations in Northern Nigeria.

\section{Acknowledgement}

The authors acknowledge all works from which this study took a leave from.

\section{Conflict of Interest}

The authors declare that there are no conflicts of interest.

\section{Bibliography}

1. Abeshu MA., et al. "Complementary feeding: Review of recommendations, feeding practices, and adequacy of homemade complementary food preparations in developing countries - Lessons from Ethiopia". Frontiers in Nutrition 3 (2016): 41.

2. Chukwu U., et al. "Chemical composition of locally made complementary food standards recipes in Nigeria”. West African Journal of Foods and Nutrition (2014): 2.

3. Anigo KM., et al. "Nutrient composition of complementary food gruels formulated from malted cereals, soybeans and groundnut for use in North-western Nigeria". African Journal of Food Science 4.3 (2010): 65-72.

4. UNICEF. Nutrition (2015).

5. WHO/Europe. "Feeding and nutrition of infants and young children” (2003).
6. Akinsola AO., et al. "Traditional complementary foods: A critical review". Greener Journal of Agricultural Sciences 7.8 (2017): 226-242.

7. Bouchenak M and Lamri-Senhadji M. "Nutritional quality of legumes, and their role in cardiometabolic risk prevention: a review". Journal of Medicinal Food 16.3 (2013): 185-198.

8. Ugwu FM. "The potentials of roots and tubers as weaning food". Pakistan Journal of Nutrition 8.10 (2009): 1701-1705.

9. Solomon M. "Nutritive value of three potential complementary foods based on cereals and legumes". African Journal of Food and Nutritional Sciences 5 (2005): 1-14.

10. Codex Alimentarius Commission. Guidelines on Formulated Complementary Foods for Older Infants and Young Children. (CAC/GL8-1991. Rev. 2013. Amended 2017) (2017): 1-10.

11. Food, Agriculture Organisation (FAO). Methods of food analysis (1998).

12. Oluwatofumni EG., et al. "Formulation and nutritional evaluation of maize, bambara groundnut and cowpea seed blends complementary food". American Journal of Food and Nutrition 3.4 (2015): 101-105.

13. Abdulrahaman AA., et al. "Traditional preparations and uses of groundnut in Nigeria". Annals of Food Science and Technology 15.1 (2014): 29-34.

14. AOAC (Association of Official Analytical Chemists). Official methods of analysis. Association of Official Analytical Chemists International. Maryland, USA (2000).

15. AOAC (Association of Official Analytical Chemists). Official methods of analysis of AOAC. (13th ed.) Washington D.C (1980).

16. Mamiro PS., et al. "Processed complementary food does not improve growth or hemoglobin status of rural tanzanian infants from 6-12 months of age in Kilosa district, Tanzania". The Journal of Nutrition 134.5 (2004): 1084-1090.

17. Lin CA., et al. "An energy-dense complementary food is associated with a modest increase in weight gain when compared with a fortified porridge in Malawian children aged 6-18 months". The Journal of Nutrition 138.3 (2008): 593-598.

18. Sanchez-Grinan MI., et al. "Effect of dietary energy density on total ad-libitum energy consumption by recovering malnourished children". European Journal of Nutrition 46.3 (1992): 197-204.

19. World Health Organisation (WHO). "Global strategy for infant and young child feeding" (2003).

20. Adenuga W. "Nutritional and sensory profiles of sweet potato based infant weaning food fortified with cowpea and peanut". Journal of Food Technology 8 (2010): 223-228. 
21. Tenegashaw MW., et al. "Nutrient density of complementary foods formulated from a blend of teff, soybean and orangefleshed sweet potato". International Journal of Food Science and Nutrition Engineering 7.4 (2017): 61-69.

22. Emmanuel-Ikpeme CA., et al. "Nutritional and sensory characteristics of an infant food based on soybean seeds (Glycine max) and tigernut tubers (Cyperusesculenta)". British Journal of Applied Science and Technology 2.4 (2012): 356-366.

23. Koletzko B., et al. "Dietary fat intakes in infants and primary school children in Germany". The American Journal of Clinical Nutrition 72 (2000): 1392S-1398S

24. Lencha EK and Bultosa G. "Effect of taro variety and soybean blending ratio on physicochemical composition, functional properties and sensory acceptability of taro-soybean-carrot based complementary food". Science and Quality Management 69 (2017): 12-20.

25. Tizazu S., et al. "Improvement of energy and nutrient density of sorghumbased complementary foods using germination". African Journal of Food, Agriculture, Nutrition and Development 10 (2010): 2928-2942.

\section{Assets from publication with us}

- Prompt Acknowledgement after receiving the article

- Thorough Double blinded peer review

- Rapid Publication

- Issue of Publication Certificate

- High visibility of your Published work

Website: https://www.actascientific.com/

Submit Article: https://www.actascientific.com/submission.php Email us: editor@actascientific.com

Contact us: +919182824667 